\title{
Evaluation of the Relationship Between Thyroid Dysfunction and Menstrual Migraine in Adult Females
}

\author{
Erişkin Kadınlarda Tiroit Disfonksiyonu ve Menstrüel Migren Arasindaki Ilişkinin \\ incelenmesi
}

\author{
(- Vasfiye Burcu Albay, ๑ Mesude Tütüncü \\ Prof. Dr. Mazhar Osman Bakırköy Psychiatric Training and Research Hospital, Clinic of Neurology, Istanbul, Turkey
}

\begin{abstract}
Aim: Menstrual migraine (MM) is a condition linked to sudden estrogen withdrawal, however, changes in vascular system and neurotransmitters and several hormones are thought to be the underlying causes. Thyroid function affects both menstrual cycle and headache, however, the relationship between thyroid hormones and MM is still not clear. The aim of the study was to evaluate the relationship of $\mathrm{MM}$ with thyroid stimulating hormone (TSH), T3, and T4.
\end{abstract}

Methods: Fifty-six patients without MM (group 1), 34 patients with MM (group 2) and 74 controls who had no migraine (group 3) were included in the study. The mean TSH, T3 and T4 levels were compared between the groups. Age, attack frequency $(A F)$, attack period (AP), visual analog scale (VAS) score, Migraine Disability Assessment (MIDAS) grade, and MIDAS score were compared between group 1 and group 2. Correlation analysis was done for TSH, T3, T4 and each of the variables for the groups.

Results: The mean T4 level in group 1, group 2 and group 3 was $1.06 \pm 1.74,0.91 \pm 0.22$ and $1.35 \pm 1.19(p=0.03)$, respectively. The mean AF was $5.66 \pm 6.37$ in group 1 and $3.08 \pm 1.81$ in group 2 $(p=0.02)$.

Conclusion: T4 was significantly lower in patients with MM compared to patients without MM, and this difference became more prominent as compared with controls. We would like to draw attention of our colleagues to the relationship between thyroid function (particularly T4 decline) and MM.

Keywords: Migraine, menstrual migraine, thyroid gland, thyroxine, triiodothyronine

\section{Öz}

Amaç: Menstrüel migren (MM) ani östrojen çekilmesine bağlı oluştuğu kabul edilen ancak altta yatan vasküler sistem, nörotransmitterler ve hormonların eşlik ettiği, karmaşık ilişkilere bağlı bir hastalıktır. Tiroit fonksiyonu hem menstrüasyon siklüsü hem de baş ağrısı ile yakın ilişki içerisindedir. Tiroit fonksiyonu ve $\mathrm{MM}$ arasındaki ilişki hala kesin olarak aydınlatılamamıştır. Çalışmamız tiroit uyarıcı hormon (TSH), T3, T4 ve MM arasındaki ilişkinin gösterilmesi amacıyla yapılmıştır.

Yöntemler: MM olmayan 56 hasta (grup 1), MM olan 34 hasta (grup 2) ve 74 baş ağrısız kontrol (grup 3) dahil edildi. TSH, T3 ve T4 hormonlarının ortalama değerleri gruplar arasında kıyaslandı. Yaş, atak sıklığı (AS), atak süresi (AP), vizüel analog skor (VAS), migren dizabilite ölçeği (MIDAS) evresi ve skoru grup 1 ve grup 2 arasında kıyaslandı. Grup 1 ve grup 2 için, TSH, T3, T4'ün her birinin VAS, MIDAS evresi, MIDAS skoru, AS, AP ile tek tek korelasyon analizi yapıldı.

Bulgular: Ortalama T4 seviyesi grup 1'de 1,06 $\pm 1,74$, grup 2'de $0.91 \pm 0.22$, grup 3 te $1,35 \pm 1,19$ saptanmıştır $(p=0,03)$. T3 ve TSH seviyeleri gruplar arasında anlamlı fark göstermemekteydi.

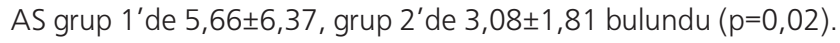

Sonuç: T4 seviyesi MM hastalarında MM olmayanlara göre anlamlı düşüktü ve bu düşüklük baş ağrısız kontrollerle kıyaslandığında daha da belirginleşmekteydi. Meslektaşlarımızı MM hastalarında tiroit fonksiyonunun (özellikle de T4 düşüşünün) takip konusunda uyarmak istedik.

Anahtar Sözcükler: Migren, menstrüel migren, tiroit bezi, tiroksin, triiodotironin
Address for Correspondence/Yazışma Adresi: Vasfiye Burcu Albay, Prof. Dr. Mazhar Osman Bakırköy Psychiatric Training and Research Hospital, Clinic of Neurology, İstanbul, Turkey E-mail: dr_burcuvdogan@hotmail.com ORCID: orcid.org/0000-0003-0428-981X Received/Geliş Tarihi: 16 July 2019 Accepted/Kabul Tarihi: 18 December 2019

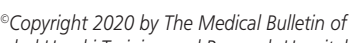
istanbul Haseki Training and Research Hospital The Medical Bulletin of Haseki published by Galenos Yayınevi. ${ }^{8}$ Telif Hakkı 2020 istanbul Haseki Eğitim ve Araştırma Hastanesi Haseki Tıp Bülteni, Galenos Yayınevi tarafından yayınlanmıştır. 


\section{Introduction}

Migraine, which is characterized by moderate to severe, pulsatile and recurrent headaches affecting typically one half of the head, is classified as a primary headache disorder by the International Headache Society (IHS). It is associated with nausea, vomiting and sensitivity to light and sound and smell (1). The disease most often starts at puberty, gets worse during middle age and decreases in severity after menopause (2). The incidence of migraine in Turkey has been reported to be $2.38 \%(2.98 \%$ for women and $1.93 \%$ for men) (3). After puberty, the prevalence of migraine in women is 2-3 times higher than in men (4). Female sex hormones have been accused for female dominance in migraine. Several studies revealed that menstrual migraine $(\mathrm{MM})$, which refers to migraine occurring in perimenstrual period (2-3 days before, during or immediately after menstruation), is seen in $7-14 \%$ of women with migraine $(5,6)$. Cyclic changes in female sex hormones, in particular sudden withdrawal of estrogen in premenstrual period has been accused in MM hypothesis (7). However, it is known that pathophysiology of MM is much more complex, and hypothalamus-pituitary-ovarian hormones, opioid control of the pituitary-adrenal axis, platelet sensitivity to prostaglandins, arterial vasodilatation and capillary constriction due to serotonin and changes in melatonin secretion play a role in the development of $\mathrm{MM}$ (6). As it is difficult to show neuroendocrine changes in migraine, in particular in MM, there are limited studies about the accused etiological factors.

In a study by Facchinetti et al. (8) including nine patients and by Awaki et al. (9) including 11 patients it was found that luteinizing hormone (LH), follicle stimulating hormone and prolactin (PRL) were similar between patients and controls whereas thyroid stimulating hormone (TSH) was lower in migraineurs than in controls. Epidemiological studies have shown a potential relationship between plasma thyroid hormones, such as triiodothyronine (T3) and thyroxine (T4), and migraine but results are contradictory (10). On the other hand, both hyperthyroidism and hypothyroidism may cause menstrual disturbances, ovulation problems and premenstrual syndrome suggesting a relationship between thyroid function and pituitary ovarian axis (11). Also, several studies revealed improvement in migraine attacks after treatment of thyroid dysfunctions $(12,13)$.

Although there is a possible relationship between thyroid function and $\mathrm{MM}$, there have been very few studies about the effect of thyroid hormones on migraine and, to the best of our knowledge, no study about the relationship of TSH, T3 and T4 with MM is present. The purpose of this study was to evaluate the relationship of MM with TSH, T3 and T4.

\section{Methods}

\section{Patients}

In this cross-sectional study, a total of 90 female patients with migraine without aura aged $18-45$ years and 74 similar-aged healthy women who attended neurology outpatient clinics between October 2017 and October 2018 were included. The participants were divided into three groups: patients without MM (group 1), patients with $\mathrm{MM}$ (group 2) and healthy controls who had no migraine (group 3).

Migraine without aura and MM were diagnosed according to the IHS and International Classification of Headache Disorders $3^{\text {rd }}$ edition (ICHD-III) beta version. Patients with secondary headache, other primary headaches, other forms of migraine, medication overuse headache, diagnosis and/or treatment of hypothyroidism, hyperthyroidism and euthyroid sick syndrome and other systemic disorders such as anemia, Diabetes Mellitus, hypertension, obesity (body mass index $>25$ ), metabolic syndrome, polycystic ovary syndrome, hepatic or renal failure, psychiatric disorders and those who were pregnant, breastfeeding, postmenopausal or using oral contraceptives and/or other hormonal medicines were excluded. The participants were administered the Beck depression inventory and Beck anxiety inventory and those who were found to have depression and/or anxiety were excluded.

The groups were subjected to blood sampling for analysis of TSH, T3 and T4 levels and other biochemical analyses during their menstrual cycle. Attack frequency (AF) which refers to the number of migraine attacks in a month, attack period (AP) which refers to the duration of each migraine attack in hours, visual analog scale (VAS) score, Migraine Disability Assessment (MIDAS) grade, and MIDAS score were recorded by a neurologist. The patients were divided into three groups according to AF as 0-2 per month, 3-10 per month and >10 per month. They were further divided according to AP into three groups as 0-12 hours, 13-24 hours and $>24$ hours.

The mean TSH, T3 and T4 levels were compared between group 1, group 2 and group 3. Then, the mean values of age, MIDAS score, MIDAS grade, AF, AP and VAS were compared between the three groups.

Correlation analysis was done for TSH, T3, T4 and each of VAS, MIDAS grade, MIDAS score, AF, AP for both group 1 and group 2.

\section{Ethics}

The study was approved by the Local Ethics Committee of Bakırköy Prof. Dr. Mazhar Osman Psychiatric Training and Research Hospital with the date and number 23.08.201729276-51688610. Informed consent was obtained from all migraine patients and controls before the study. 


\section{Statistical Analysis}

The Statistical Package for the Social Sciences for Windows version 22 was used for data analysis. Parametric variables such as age and TSH, T3 and T4 levels were presented by mean and standard deviations. Chi-square test and, if necessary, Fischer's exact test were used in categorical variables. The non-parametric MannWhitney $U$ test was used to compare the instruments of the two groups that were not normally distributed and the normal distributions were compared using the student's t-test. Correlation analysis was evaluated by Spearman's correlation test in non-normally distributed data and Pearson's correlation coefficient in normally distributed data. A p value of less than $0.05,0.01$ and 0.001 was considered statistically significant, statistically highly significant and statistically extremely significant, respectively.

\section{Results}

MM was found in $34(37.8 \%)$ patients. The mean age of the patients in group 1, 2 and 3 was $33.4 \pm 8.50$, $33.32 \pm 8.04$ and $33.2 \pm 7.9$, respectively $(p=0.93)$. There was no significant difference in demographic characteristics between the groups. The mean TSH, T3 and T4 levels in group 1, group 2 and group 3 are given in Table 1. There was no significant difference in the mean TSH $(p=0.09)$ and T3 $(p=0.70)$ levels between the groups. The mean T4 level in group 1, 2 and 3 was $1.06 \pm 1.74,0.91 \pm 0.22$ and $1.35 \pm 1.19$, respectively $(p=0.03)$. The mean $\mathrm{T} 4$ level was significantly lower in patients with MM than in patients without $\mathrm{MM}$, and more prominently than in controls.

The mean VAS was 7 for both group 1 and group 2 . The AF was 0-2 per month in 20 (35.7\%) patients, 3-10 per month in $31(55.4 \%)$, and $>10$ per month in five $(8.9 \%)$ in group 1 whereas 0-2 per month in 15 (44.1\%) patients, 3-10 per month in 19 (55.9\%), and $>10$ per month in zero $(0.0 \%)$ patients in group 2 . AP was $0-12$ hours in $28(50.0 \%)$ patients, $13-24$ hours in $18(32.1 \%)$ and $>24$ hours in $10(17.9 \%)$ in group 1 , whereas $0-12$ hours in seven (20.6\%) patients, $13-24$ hours in 18 (52.9\%), and $>24$ hours in nine (26.5\%) in group 2. In group 1, 10 (17.6\%) patients had MIDAS grade 1, 15 (26.9\%) - grade

\begin{tabular}{l|l|l|l|l|l|}
\hline $\begin{array}{l}\text { Table 1. Mean levels of TSH, T3, T4 in group 1, group } 2 \text { and } \\
\text { group 3 }\end{array}$ \\
\hline Mean & $\begin{array}{l}\text { Group 1 } \\
(\mathbf{n}=56)\end{array}$ & $\begin{array}{l}\text { Group 2 } \\
(\mathbf{n}=34)\end{array}$ & $\begin{array}{l}\text { Group 3 } \\
(\mathbf{n}=70)\end{array}$ & $\mathbf{p}$ \\
\hline TSH & $1.88 \pm 0.97$ & $2.42 \pm 1.73$ & $2.37 \pm 1.56$ & 0.09 \\
\hline T3 & $3.39 \pm 0.50$ & $3.30 \pm 0.55$ & $3.29 \pm 0.85$ & 0.70 \\
\hline T4 & $1.06 \pm 1.74$ & $0.91 \pm 0.22$ & $1.35 \pm 1.19$ & 0.03 \\
\hline
\end{tabular}

TSH: Thyroid stimulating hormone; T3: Thyroxine; T4: Triiodothyronine; $\mathrm{n}$ : Number
2, $16(28.6 \%)$ - grade 3 and 15 (26.9\%) - grade 4 . In group 2 , four (11.8\%) patients had MIDAS grade 1, 15 (44.1\%) - grade 2, 11 (32.3\%) - grade 3 and four (11.8\%) - grade 4. Comparison of mean values of MIDAS grade, MIDAS score, AF and AP between group 1 and group 2 is given in Table 2. The only significant difference between the groups was in AF ( $p=0.02)$.

Correlation between TSH, T3 and T4 levels and each of VAS, MIDAS grade, MIDAS score, AF and AP in group 1 and group 2 is given in Table 3 . The only significant correlation was detected between VAS and TSH level in group $1(r=+0.43, p=0.009)$ whereas no other parameters had a significant correlation between each other.

\section{Discussion}

MM is defined as migraine without aura occurring during the menstrual window, starting 2-3 days before the onset of menstrual bleeding and lasting until the third day of menstruation, and that occurs in at least two-thirds of menstrual cycles (14). Clinically, MM has been found to be more disabling when associated with migraine chronicity and medication overuse. The prevalence of $\mathrm{MM}$ among migraineurs is $42-61 \%$ (15). The etiology of $\mathrm{MM}$ is sudden estrogen withdrawal in the late luteal phase. Estrogen receptors (ER) such as ER $\alpha$ and ER $\beta$ are expressed not only in female genital system, but also throughout the central and peripheral nervous systems, particularly in trigeminal pain pathways. Estrogen decline directly affects other neurotransmitters qualitatively and quantitatively, particularly it decreases serotonin and beta-adrenergic receptors, increases sensitivity of dopaminergic receptors, and modulates the anti-nociceptive activity of opioids (16). Although it has been reported that hypothalamicpituitary-ovarian axis plays major role in the development of $\mathrm{MM}$ as rising estrogen during ovulation stimulates alfa1-adrenoreceptors of vascular smooth muscles that increases contraction which may be responsible for the decreased cerebral blood flow and migraine attack, a variety of other hormonal changes are also accused to play a role in $\mathrm{MM}(6,15)$. In a study by Nattero and his colleagues, including 10 women, nocturnal aldosterone drop was detected at the onset of MM attack when daily

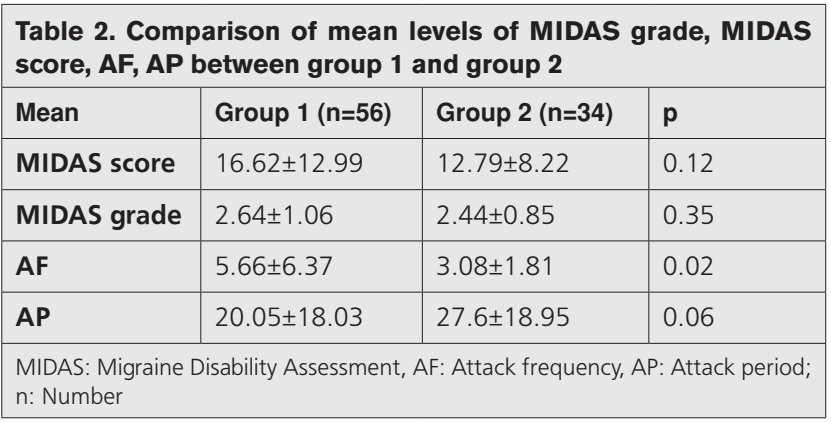


aldosterone, renin, cortisol, sodium, potassium were all in normal levels. Murialdo et al. (17) reported decreased nocturnal urinary melatonin excretion throughout an ovarian cycle in 12 patients with migraine without aura which may be an evidence of impaired pineal function in migraine. Plasma levels of norepinephrine and dopamine have been reported to be lower in migraine patients during premenstrual period (18). When thyrotropin releasing hormone, LH and insulin were simultaneously loaded to migraineours and controls PRL was significantly and TSH was non-significantly increased as compared with controls (9). In a study by Rubino et al. (19) including 151 patients and 150 controls, migraine was detected more frequently in patients with subclinical hypothyroidism.

Several studies revealed that there was a strong association between thyroid dysfunction and migraine even if thyroid hormones are higher or lower (20). Enhanced level of thyroid hormones increased oxidative state in tissues where the metabolic rates are higher. Particularly, the fact that they increase lipid per-oxidation, decrease antioxidant enzymatic activities and decrease gamma-aminobutyric acid synthesis in the brain may be a trigger for migraine $(21,22)$. On the other hand, inadequate thyroid function results in slower metabolism, which in turn causes the body to retain fluid and mucin glycoprotein as a result of inappropriate secretion of antidiuretic hormone and this process eventually causes vasodilatation and swelling of brain tissue, which can result in cerebral hyperactivity causing migraine (23). However, pathophysiological relationship between thyroid dysfunction and migraine and $\mathrm{MM}$ is still not clear yet. Recently, it was reported that thyroid receptors (TR) are also present human oocytes and act on ovarian follicles and down regulation of TRs decrease the follicle number and fertility (24). Low levels of thyroid hormones cause decreased activity of sex hormone binding globulin resulting in decreased plasma concentration of estrogen which is the main hormone accused not just for infertility but also for MM. On the other hand, estrogen may have direct or indirect effects on thyroid gland via receptordependent and-independent mechanisms. ER was first reported in human thyroid tissues in 1981 and it has a direct role in thyroid follicular cells and influences the growth and function of the thyroid gland (25). Estrogen can mimic thyroid-binding globulin (TBG) and increase the conversion of T3 (the active form of thyroid hormone) to T4 (the inactive form of thyroid hormone) which means that there is a positive correlation between estrogen and T4 levels and, estrogen dominance may result in symptoms of hypothyroidism (26). According to this information, when estrogen withdrawal occurs in MM, TBG mimicking activity of estrogen decreases, thus, binding T4 level decreases.

To the best of our knowledge, this is the first study investigating the relationship of MM with TSH, T3 and T4. In the current study, alterations in TSH, T3 and T4 levels in patients with $\mathrm{MM}$, patients without $\mathrm{MM}$ and healthy individuals and the relationship between TSH, T3, T4 and characteristics of migraine were examined. The patients with $\mathrm{MM}$ had significantly lower AF as compared with those without MM whereas their AP were slightly higher suggesting that they have less attacks with longer durations. However, this finding was not correlated with TSH, T3 and T4 levels in patients with MM. The most important finding of the current study is that T4 level was significantly lower in patients with $\mathrm{MM}$ than in patients without $\mathrm{MM}$, and this difference became more prominent as compared with controls. T4 decline is compatible with the mechanism of estrogen mimicking activity of TBG whereas there was no difference in terms of T3 between the groups.

Table 3. Correlation between TSH, T3, T4 levels and each of VAS, MIDAS grade, MIDAS score, AF, AP in group 1 and group 2

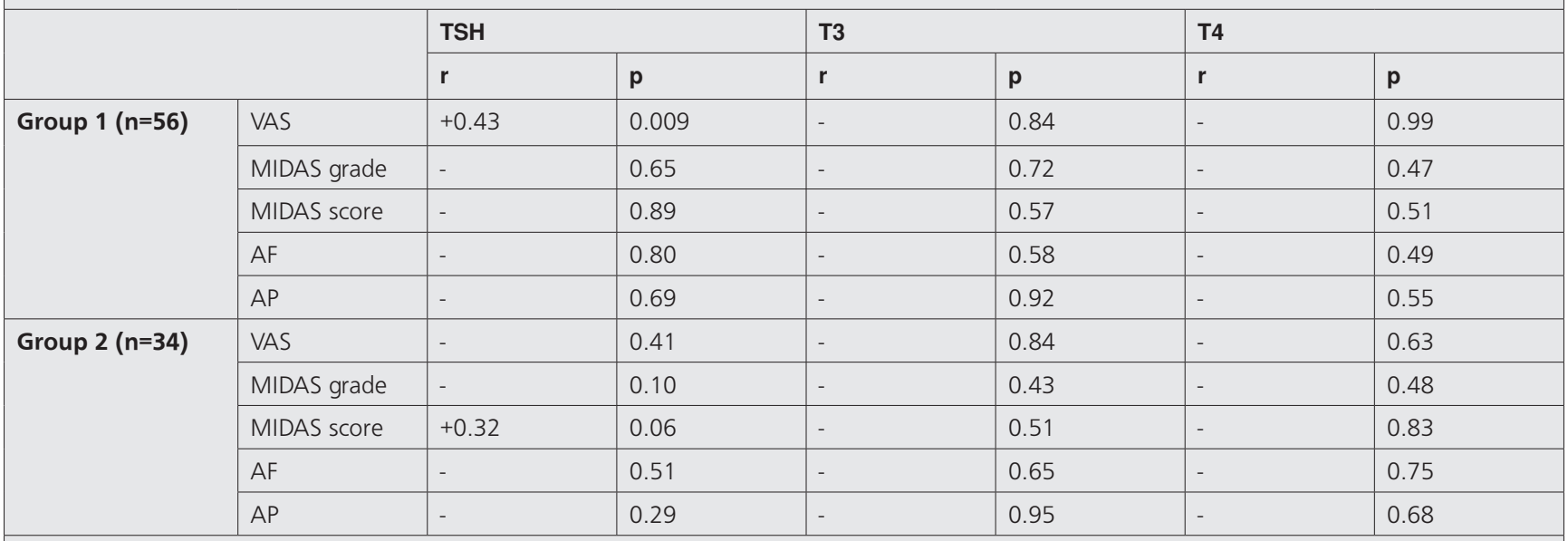

TSH: Thyroid stimulating hormone; T3: Triiodothyronine; T4: Thyroxine; VAS: Visual analog score; MIDAS: Migraine Disability Assessment; AF: Attack frequency; AP: Attack period 


\section{Study Limitations}

Absence of autoimmune thyroid antibody analysis and absence of investigation of multiple blood samples at particular times of the menstrual period might be the limitations of this study.

\section{Conclusion}

It may be important to pay attention that patients with MM have less AF with longer duration and there is a relationship between thyroid function, particularly T4 decline, and MM. Further studies investigating the complex relationship between thyroid function and $\mathrm{MM}$ are warranted.

\section{Authorship Contributions}

Concept: V.B.A. Design: V.B.A. Data Collection or Processing: M.T. Analysis or Interpretation: V.B.A., M.T. Literature Search: V.B.A., M.T. Writing: V.B.A.

Conflict of Interest: No conflict of interest was declared by the authors.

Financial Disclosure: The authors declared that this study received no financial support.

\section{References}

1. Sprenger T, Goadsby PJ. Migraine pathogenesis and state of pharmacological treatment options. BMC Med 2009;7:71.

2. Sacco S, Ricci S, Degan D, Carolei A. Migraine in women: the role of hormones and their impact on vascular diseases. J Headache Pain 2012;13:177-89.

3. Baykan B, Ertas M, Karlı N, et al. Migraine incidence in 5 years: a population-based prospective longitudinal study in Turkey. J Headache Pain 2015;16:103.

4. Steiner TJ, Scher Al, Stewart WF, Kolodner K, Liberman J, Lipton RB. The prevalence and disability burden of adult migraine in England and their relationships to age, gender and ethnicity. Cephalalgia 2003;23:519-27.

5. MacGregor EA, Frith A, Ellis J, Aspinall L, Hackshaw A. Incidence of migraine relative to menstrual cycle phases of rising and falling estrogen. Neurology 2006;67:2154-8.

6. Benedetto C, Allais G, Ciochetto D, De Lorenzo C. Pathophysiological aspects of menstrual migraine. Cephalalgia 1997;17:32-4.

7. Vetvik KG, MacGregor EA, Lundqvist C, Russell MB. Prevalence of menstrual migraine: A population-based study. Cephalalgia 2014;34:280-8.

8. Facchinetti F, Sances G, Volpe A, et al. Hypothalamus pituitaryovarian axis in menstrual migraine: effect of dihydroergotamine retard prophylactic treatment. Cephalalgia 1983;3:159-62.

9. Awaki E, Takeshima T, Takahashi K. A neuroendocrinological study in female migraineurs: prolactin and thyroid stimulating hormone responses. Cephalalgia 1989;9:187-93.
10. Rainero I, Rubino E, Vicenti C, et al. Prevalence of migraine in subclinical hypothyroidism: a case-control study. J Headache Pain 2015;16:A81.

11. Ajmani NS, Sarbhai V, Yadav N, Paul M, Ahmad A, Ajmani AK. Role of Thyroid Dysfunction in Patients with Menstrual Disorders in Tertiary Care Center of Walled City of Delhi. J Obstet Gynaecol India 2016;66:115-9.

12. Singh SK. Prevalence of migraine in hypothyroidism. J Assoc Physicians India 2002;50:1455-6.

13. Moreau T, Manceau E, Giroud-Baleydier F, Dumas R, Giroud $M$. Headache in hypothyroidism. Prevalence and outcome under thyroid hormone therapy. Cephalalgia 1998;18:687-9.

14. Peterlin BL, Calhoun AH, Balzac F. Men, women, and migraine: the role of sex, hormones, obesity, and PTSD. J Fam Pract 2012;61:7-11.

15. Martin VT. New Theories in the pathogenesis of menstrual migraine. Curr Pain Headache Rep. 2008;12:453-62.

16. Lee CW, Ho IK. Sex differences in opioid analgesia and addiction: interactions among opioid receptors and estrogen receptors. Mol Pain 2013;9:45.

17. Murialdo G, Fonzi S, Costelli $P$, et al. Urinary melatonin excretion throughout the ovarian cycle in menstrual related migraine. Cephalalgia 1994;14:205-9.

18. Fioroni L, Martignoni E, Facchinetti F. Changes in neuroendocrine axes in patients with menstrual migraine. Cephalalgia 1995;15:297-300.

19. Rubino E, Rainero I, Garino F, et al. Subclinical hypothyroidism is associated with migraine: A case-control study. Cephalalgia 2019;39:15-20.

20. Lisotto C, Mainardi F, Maggioni F, Zanchin G. The comorbidity between migraine and hypothyroidism. J Headache Pain 2013;14:138.

21. Das K, Chainy GB. Thyroid hormone influences antioxidant defense system in adult rat brain. Neurochem Res 2004;29:1755-66.

22. Tamijani SMS, Karimi B, Amini E, et al. Thyroid hormones: Possible roles in epilepsy pathology. Seizure 2015;31:155-64.

23. Chinitz A, Turner FL. The association of primary hypothyroidism and inappropriate secretion of antidiuretic hormone. Arch Intern Med 1965;116:871-4.

24. Saran S, Gupta BS, Philip R, et al. Effect of hypothyroidism on female reproductive hormones. Indian J Endocrinol Metab. 2016;20:108-13.

25. Santin AP, Furlanetto TW. Role of estrogen in thyroid function and growth regulation. J Thyroid Res 2011;2011:875125.

26. Welch KM, Brandes JL, Berman NE. Mismatch in how oestrogen modulates molecular and neuronal function may explain menstrual migraine. Neurol Sci 2006;27:190-2. 